\title{
STRATEGI KERJASAMA SISTER CITY KOTA BANDUNG DENGAN PETALING JAYA DI BIDANG EKONOMI
}

\section{PERDAGANGAN}

\author{
Gia Anggia1), Titin Rohayatin'), Lukman Munawar F3)
}

1), 2), 3)Prodi Ilmu Pemerintahan, Fakultas Ilmu Sosial dan Ilmu Politik,

Universitas Jenderal Achmad Yani Cimahi - Bandung

\begin{abstract}
Abstrak
Kota Bandung dengan Petaling Jaya melakukan Kerjasama Sister City pada bidang ekonomi perdagangan yang dimulai dari tahun 2012 dan berlanjut 2015 . UMKM yang ada di Kota Bandung masih banyak mendapatkan permasalahan dalam menjalankan bisnisnya dan UMKM masih sulit berkembang. Penelitian deskritif dengan pendekatan kualitatif. Teknik pengumpulan melalui pengumpulan data primer (wawancara dan observasi), serta pengumpulan data sekunder (studi kepustakaan). Hasil penelitian strategi kerjasama Sister City Kota Bandung dengan Petaling Jaya di bidang ekonomi perdagangan dapat dikatakan belum optimal. Hal itu terlihat, kurangnya kesadaran dari sumber daya aparatur terhadap penguasaan Bahasa Inggris, aparatur belum menyadari bahwa penguasaan bahasa dapat meningkatkan kualitas kinerja pegawai dalam sebuah strategi kerjasama Sister City dengan Petaling Jaya di bidang ekonomi perdagangan khususnya dalam mempromosikan produk-produk UMKM Kota Bandung. Kedua Pemerintah Kota Bandung tidak mempunyai strategi khusus untuk mengatasi ancaman yang dihadapi mengenai kerjasama Sister City dengan petaling Jaya di bidang ekonomi perdagangan, ketiga strategi kerjasama melalui kolaborasi dalam kegiatan promosi di Petaling Jaya.
\end{abstract}

Kata Kunci: Strategi, Sister City, UMKM

\begin{abstract}
The City of Bandung and Petaling Jaya have collaborated with Sister City in the trade economy sector starting from 2012 and continuing in 2015. MSMEs in Bandung still have many problems running their business and MSMEs are still having difficulty developing. Descriptive research with a qualitative approach. Techniques based on primary data (interviews and observations), as well as secondary data (literature study). The results of the research on the collaboration strategy of Sister City Bandung City with Petaling Jaya in the economic sector can be said to be not optimal. This can be seen, the lack of awareness of the apparatus' resources towards mastery of English, the apparatus has not realized that language acquisition can improve the quality of employee performance in a collaboration strategy between Sister City and Petaling Jaya in the trade economy sector in the field of MSME products in Bandung City. The two Bandung City Governments do not have a specific strategy to overcome the threats associated with Sister City with Petaling Jaya in the trade economy, the three strategies of cooperation through promotional activities in Petaling Jaya.
\end{abstract}

Keywords: Strategy, Sister City, Small Medium Enterprise 


\section{PENDAHULUAN}

Melihat semakin luasnya peran yang diberikan oleh Pemerintah Pusat kepada Daerah untuk mendukung otonomi daerah menjadikan daerah-daerah di Indonesia berlomba-lomba untuk menjalin kerjasama antar kota di seluruh dunia. Berkaitan dengan kerjasama salah satu bentuk kerjasama daerah yang populer di negara-negara belahan dunia termasuk di Indonesia salah satunya yaitu yang dinamakan kerjasama Sister City sering juga disebut dengan Twining City atau dalam bahasa Indonesia sebagai kota kembar merupakan kerjasama yang terjalin antar kota yang bersifat luas, disepakati secara resmi dan bersifat jangka panjang. Istilah Sister City digunakan oleh Kementerian Dalam Negeri dan Kementerian Luar Negeri, dengan keluarnya surat Edaran Menteri Dalam Negeri No.193/1652/PUOD tanggal 26 April 1993 perihal tata cara pembentukan Hubungan Kerjasama Antar Kota (Sister City) dan Antar Provinsi (Sister Province) dalam dan luar negeri.

Sister City bermula pada saat era globalisasi membawa pola-pola interaksi dalam hubungan Internasional yang berujung pada upaya agar dunia menjadi terintergrasi antara satu dengan yang lainnya, maka munculah Pemerintahan Lokal atau Local Government. Sebagaimana Pamudji dalam Amirullah (2010: 98), "kerjasama antar daerah kerjasama pada hakekatnya mengindikasikan adanya dua pihak atau lebih yang berinteraksi secara dinamis untuk mencapai suatu tujuan bersama." Dalam pengertian itu terkandung tiga unsur pokok yang melekat pada suatu kerangka kerjasama, yaitu unsur dua pihak atau lebih, unsur interaksi dan unsur tujuan bersama.

Jika satu unsur tersebut tidak termuat dalam satu obyek itu tidak terdapat kerjasama. Unsur dua pihak, selalu menggambarkan suatu himpunan yang satu sama lain saling mempengaruhi sehingga interaksi untuk mewujudkan bersama penting dilakukan. Kerjasama dapat dilakukan dengan beberapa bentuk perjanjian dan pengaturan. Hal ini dijelaskan oleh Rosen dalam Keban (2007:33) bahwa bentuk perjanjian 
Form of agreements dibedakan yaitu: "handshake agreements atau pengaturan kerjasama yang tidak didasarkan atas perjanjian tertulis dan written agreement atau pengaturan kerjasama yang didasarkan atas perjanjian tertulis.

Kota Bandung mempunyai banyak hubungan kerjasama luar negeri. Salah satu yang dibentuk oleh Kota Bandung adalah kerjasama Luar Negeri dengan kota lain yang berasal dari negara lain yang memiliki tujuan sama, yaitu ingin memberi masukan bagi perkembangan masing-masing pihak. Kota Bandung menjalin kerjasama Sister City dengan Petaling Jaya (Malaysia). Dua Kota ini bekerjasama dan bertukar pengetahuan soal pengembangan pembangunan untuk kemajuan bersama.

Walikota Bandung Ridwan Kamil meresmikan monumen Kota Bandung di Kota Petaling Jaya, Malaysia, Jumat 27 November 2015. Ada beberapa bidang kerjasama yang disepakati untuk melakukan kerjasama, salah satunya dalam bidang ekonomi perdagangan yaitu khusunya sektor UMKM. Pada tanggal 17 Juli 2012, Letter of Intent (Lol) Pemerintah Kota Bandung, Provinsi Jawa Barat, dan Bandaraya Petaling Jaya, Selangor Darut Ehsan, Malaysia, dengan surat perjanjian yang ditandatangani oleh Dada Rosada Walikota Bandung dan Rosman Sakiman Datuk Bandar Petaling Jaya, dimaksudkan sebagai mitra berkeinginan untuk meningkatkan hubungan persaudaran dan saling pengertian, serta kerjasama yang saling menguntungkan antara Pemerintah Kota Bandung, Provinsi Jawa Barat, Republik Indonesia dan Bandaraya Petaling Jaya, Selangor Darut Ehsan, Malaysia, mengingat pentingnya prinsip-prinsip kesetaraan yang saling menguntungkan, menyatakan keinginan untuk meneruskan perjanjian kerjasama ke dalam Memorandum saling Pengertian atas kerjasama Mitra Kota sebagai dasar kerjasama yang lebih jauh dalam bidang-bidang berikut: 1. Ekonomi dan Perdagangan; 2. Pariwisata; 3. Pendidikan; dan 4. Bidang lain yang akan disetujui kemudian (Sekertaris Daerah Bagian Kerjasama Kota Bandung, 2017). 
Tujuan kerjasama Sister City Kota Bandung dengan Kota Petaling Jaya dalam bidang ekonomi tentunya, untuk membantu mempercepat pertumbuhan ekonomi, menggali dan mengembangkan potensi kedua daerah, memenuhi kebutuhan daerah, membantu membebaskan kemiskinan, memajukan perdagangan dengan maksud meningkatkan kemakmuran kedua daerah Sister City. Saat ini UMKM seperti Fashion, Craft, Kuliner dan Kerajinan yang ada di Kota Bandung malah lebih banyak menghadapi masalah, seperti rendahnya produktivitas, keterbatasan akses kepada sumber daya produktif seperti modal, teknologi, informasi dan pasar, kualitas sumber daya manusia yang rendah serta iklim usaha yang belum menunjang secara optimal. Ditambah lagi, situasi globalisasi yang menyulitkan berkembang lebih optimal, kemampuan memenuhi permintaan produk yang berkualitas untuk menghasilkan produk yang bisa berdaya saing di pasaran masih jauh dari jumlah permintaan yang sebenarnya dapat dipenuhi oleh UMKM, sedangkan kebanyakan kebutuhan tidak bisa menunggu. Akibatnya peluang yang ada tersebut diisi oleh usaha-usaha skala besar dan UMKM pun menjadi sulit berkembang.

\section{METODE PENELITIAN}

Penelitian ini menggunakan metode deskritif dengan menggunakan pendekatan kualitatif. Karekteristik penelitian kualitatif menurut Bogdan dan Biklen dalam (Sugiyono, 2013) yaitu: dilakukan pada kondiis yang alamiah; penelitian kualitatif lebih bersifat deskritif; kualittaif menekankan pada proses dari pada produk outcome; peneltiian kualitatif melakukan analisis data secara induktif; peneliti kualitatif lebih menekankan makna (data dibalik yang diamati).

\section{PEMBAHASAN}

Kota Bandung yang dipimpin oleh M. Ridwan Kamil selaku Walikota melakukan kerjasama Sister City salah satunya dengan Kota Petaling Jaya Malaysia dalam hal ini juga peneliti memfokuskan pada bidang ekonomi perdagangan khususnya sektor UMKM yang dikerjasamakan oleh Kota 
Bandung dengan Petaling Jaya, maka dari itu perlu adanya sebuah strategi agar Pemerintah Kota Bandung bisa memanfaatkan secara maksimal kerjasama tersebut.

\section{A. Mencapai menyepakati suatu proses perencanaan strategis}

\section{1) Langkah-langkah yang dilakukan}

Langkah-langkah yang dilakukan Kota Bandung dalam hal kerjasama dengan Petaling Jaya dibidang ekonomi perdagangan bisa menentukan berjalan baik atau tidaknya sebuah kerjasama tersebut. Jadi apa yang dilakukan oleh Pemerintah Kota Bandung dalam hal kerjasama Sister City dengan Petaling Jaya haruslah benar-benar bisa mengoptimalkan sebuah kerjasama tersebut dengan langkah yang dilakukan Pemeintah Kota Bandung.

Menurut hasil wawancara dengan Kasubag Adminstrasi, Dokumentasi, dan Evaluasi Kerjasama SETDA Kota Bandung yang dilakukan pada tanggal 31 Juli 2017 terkait dengan bagaimana langkah-langkah yang telah dilakukan oleh Pemerintah Kota Bandung dalam kerjasama Sister City dengan Petaling Jaya di bidang ekonomi perdagangan menyatakan bahwa:

"Pemerintah selalu berupaya memberikan yang terbaik untuk kepentingan Kota Bandung dan masyarakat bandung didalamnya, langkah-langkah yang dilakukan oleh Pemerintah Kota Bandung dalam kerjasama Sister City dengan Petaling Jaya di bidang ekonomi perdagangan yaitu selalu mengedepankan komunikasi dengan Pemerintah Petaling Jaya guna mengintensifkan kerjasama di bidang ekonomi perdagangan khususnya di sektor UMKM karena sampai saat ini Kota Bandung dan Petaling Jaya bekerjasama memfokuskan pada ekonomi kreatif atau UMKM saja yang dilakukan di bidang ekonomi perdagangan, adapun langkah-langkah atau upaya yang telah dilakukan Pemerintah Kota Bandung sampai saat ini selain menjaga komunikasi secara intensitas dengan pihak Petaling Jaya, selai itu langkah-langkah yang telah dilakukan oleh Pemerintah Kota Bandung dalam menjalin sebuah kerjasama Sister City dengan Petaling Jaya di bidang ekonomi perdagangan khususnya di sektor UMKM yaitu dengan memperkuat daya saing produk Kota Bandung. Pemerintah Kota Bandung telah mempersiapkan program untuk memaksimalkan atau mendukung kerjasama Sister City dengan Petaling Jaya, adapun program tersebut yaitu yang bernama Little Bandung." 
Dari hasil wawancara yang telah dilakukan oleh peneliti mengenai atau terkait bagaimana langkah-langkah yang telah dilakukan oleh Pemerintah Kota Bandung dalam kerjasama Sister City dengan Petaling Jaya di bidang ekonomi perdagangan khsusnya sektor ekonomi kreatif atau UMKM, dari hasil wawancara tersebut telah memberikan informasi kepada peneliti bahwa Pemerintah Kota Bandung telah melakukan langkahlangkah kongkrit berupa strategi dari Pemerintah Kota Bandung itu sendiri dengan menggandeng program Little Bandung yang memang telah dipersiapkan untuk mempromosikan produk-produk Kota Bandung dalam dunia Intenernaional salah satunya dilakukan dalam sebuah kerjasama Sister City Kota Bandung dengan Petaling Jaya dibidang ekonomi perdagangan, hal ini dalam upaya memaksimalkan atau mendorong kerjasama Sister City dengan Petaling Jaya di bidang ekonomi perdagangan melalui program Little Bandung.

\section{Gambar 1. Little Bandung Catalogue}

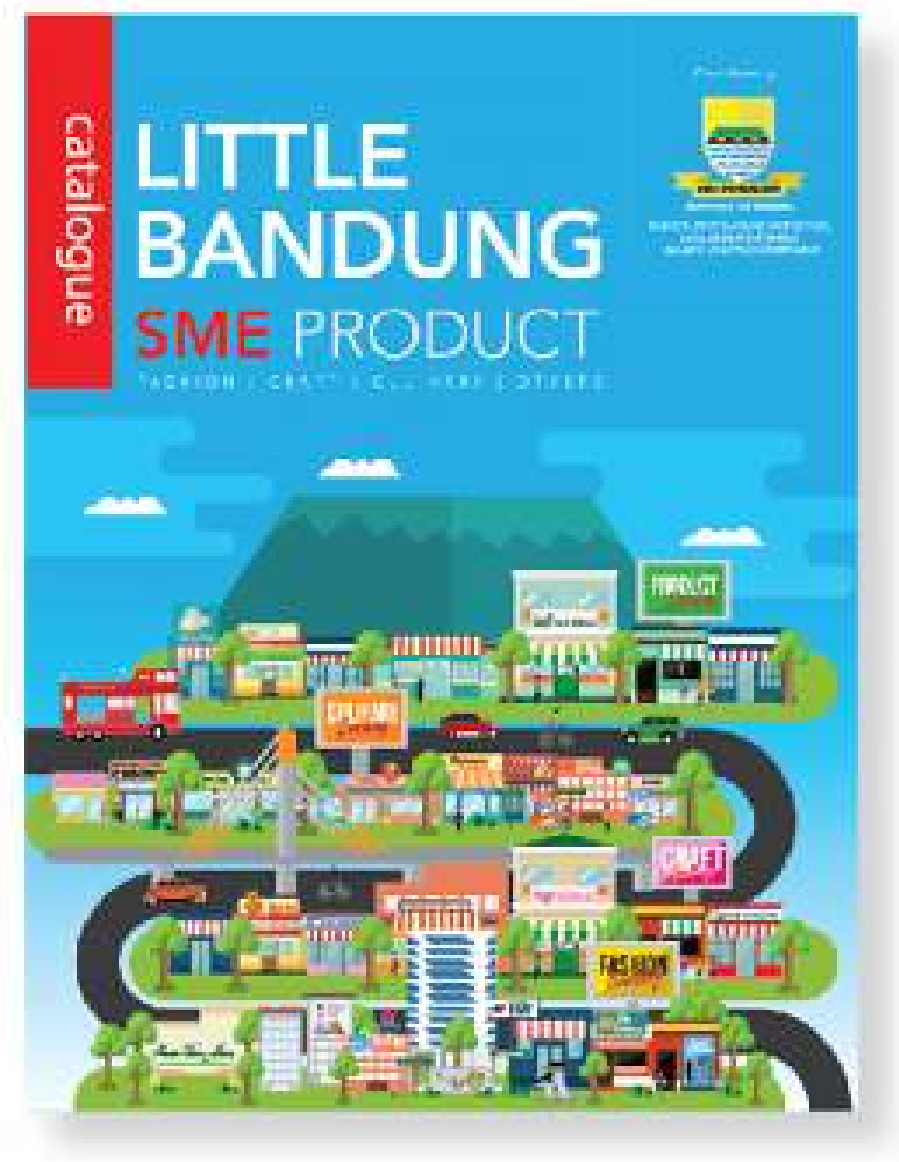

(https://littlebandung.co.id/littlebandungcatsmeprod/) 
Gambar di atas Program Little Bandung, program Litlle Bandung adalah salah satu program dukungan Pemerintah Kota Bandung untuk memperkuat daya saing produk Kota Bandung, mendorong partisipasi UMKM Kota Bandung dalam rantai nilai global sehingga bisa aktif dalam bisnis ekonomi perdagangan internasional dan berkontribusi nyata terhadap perekonomian Kota Bandung dan perekonomian negara. Program dibuat dalam mempromosikan produk Bandung di dalam negeri dan internasional. Ada 5 program yang telah dimulai Little Bandung yaitu:

1. Litlle Bandung Store

2. Little Bandung Mobile

3. Little Bandung Catalogue

4. Little Bandung Wall

5. Little Bandung F4bdg.

Program Lillte Bandung mempunyai 5 program yang dimana program tersebut dilaksanakan untuk meningkatkan promosi Kota Bandung dalam memasarkan produk-produk UMKM Kota Bandung di tingkat pasar nasional maupun pasar global/internasional. 5 program Little Bandung tersebut sejalan dalam upaya meningkatkan kerjasama Sister City yang dilakukan Kota Bandung denga Petaling Jaya di bidang ekonomi perdagangan.

\section{2) Sarana dan prasarana}

Sarana dan prasarana merupakan sesuatu yang dapat dipakai sebagai alat dalam mencapai maksud atau tujuan dan segala sesuatu yang merupakan penunjang utama dalam kerjasama Sister City yang dilakukan Pemerintah Kota Bandung dengan Petaling Jaya di bidang ekonomi perdagangan. Lebih dari itu sarana dan prasarana sebagai suatu pendukung kesuksesan sebuah kerjasama yang dilakukan oleh Pemerintah Kota Bandung.

Menurut wawancara dengan Kasubag Adminstrasi, Dokumentasi, dan Evaluasi Kerjasama SETDA Kota Bandung yang dilakukan pada tanggal 31 Juli 2017 terkait bagaiamana sarana Bandung untuk mendukung kerjasama Sister City dengan Petaling Jaya menyatakan 
bahwa :

"Ada beberapa dari sarana dan prasana yang dimiliki Pemerintah Kota Bandung dalam hal kerjasama Sister City dengan Petaling Jaya di bidang ekonomi perdagangan yang bisa dimanfaatkan dan bisa dikatakan cukup memadai salah satunya E-Commerce yang ada atau dimiliki Kota Bandung, ECommerce merupakan bagian dari sarana dan prasarana yang dimiliki yang dapat dimanfaatkan sebagai kunci faktor keberhasilan kerjasama, selain itu juga kebutuhan teknis seperti paket internet atau wifi sangat menunjang untuk menjalin komunikasi hubungan kerjasama."

Hasil wawancara tersebut memberikan informasi kepada peneliti bahwa sarana dan prasarana yang ada di Kota Bandung sejauh ini dapat dimanfaatkan seperti E-Commerce yang dimiliki Kota Bandung dalam menjalin kerjasama Sister City dengan Petaling Jaya di bidang ekonomi perdagangan. Hal tersebut menjadi bagian terpenting dalam sebuah kerjasama yang dilakukan oleh Pemerintah Kota Bandung. Selain melakukan wawancara, peneliti juga melakukan observasi terhadap sarana dan prasarana yang memang salah satu yang disebutkan oleh informan mengenai E-Commerce dengan menunjukan E-Commerce yang ada di Pemerintah Kota Bandung sangatlah bermanfaat untuk mendukung kerjasama Sister City dengan Petaling Jaya di bidang ekonomi perdagangan, yaitu dengan membuka pasar produk untuk di Petaling Jaya. Dari hasil penelitian terkait sarana dan prasarana yang dapat dimanfaatkan Pemerintah Kota Bandung dalam mendukung kerjasama Sister City dengan Petaling Jaya di bidang ekonomi perdagangan ada hal yang bisa dimanfaatkan yaitu salah satunya E-Commerce yang dimiliki Kota Bandung selain itu juga ada sarana penunjang lainnya seperti paket internet ataupun WIFI.

\section{B. Mengidentifikasi mandat organisasi}

\section{1) Identifikasi kebutuhan}

Identifikasi kebutuhan untuk menjalankan suatu fungsi organisasi dari Pemerintah Kota Bandung dalam kerjasama Sister City yang dilakukan dengan Petaling Jaya. Menurut hasil wawancara dengan Kasubag Adminstrasi, Dokumentasi, dan Evaluasi Kerjasama SETDA Kota Bandung 
yang dilakukan pada tanggal 31 Juli 2017 terkait dengan bagaimana kebutuhan yang diperlukan dalam menjalankan suatu fungsi organisasi menyatakan bahwa:

"Sejauh ini respon respon dari setiap Dinas yang berada di Kota Bandung sangat bagus untuk saling melengkapi satu sama lain dan saling memenuhi kebutuhannya satu sama lain dalam melihat potensi yang ada, setiap organisasi memiliki kebutuhan untuk mencapai tujuan tersebut. Kebutuhan tersebut berupa kebutuhan fisik, financial, dan sumber daya manusia dalam menjalankan sebuah fungsi organisasi."

Hasil wawancara tersebut memberikan informasi kepada peneliti bahwa Pemerintah Kota Bandung menjalankan sinergitas yang baik antar lembaga dalam upaya memenuhi suatu kebutuhannya agar apa yang menjadi tujuan bersama menjadi terlaksana dengan baik, dan apabila kebutuhan seperti kebutan fisik, financial dan sumber daya manusia belum terpenuhi maka dikordinasikan untuk memenuhi kebutuhan tersebut, artinya bahwa Pemerintah Kota Bandung berupaya dalam hal memenuhi kebutuhan organisasi guna mendukung atau menunjang untuk mencapai sebuah tujuan yang diinginkan sesuai dengan visi dan misi yang ada di Pemerintahan Kota Bandung.

\section{2) Menggunakan informasi dalam upaya analisis}

Adapun informasi dalam upaya analisis yaitu bagaimana kebutuhan Pemerintah Kota Bandung dalam hal kerjasama Sister City dengan Petaling Jaya di bidang ekonomi perdagangan serta apa saja target yang ingin dicapai atau di raih oleh Pemerintah Kota Bandung dalam hal kerjasama Sister City dengan Petaling Jaya.

Menurut hasil wawancara dengan Kepala seksi Usaha Menengah, Bidang UKM Dinas KUMKM pada tanggal 25 Juli 20117 terkait dengan bagaimana kebutuhan Pemerintah Kota Bandung dalam hal kerjasama Sister City dengan Petaling Jaya dibidang ekonomi perdagangan khususnya sektor UMKM serta apa saja target yang ingin dicapai atau diraih oleh Pemerintah Kota Bandung menyatakan bahwa:

"Kebutuhan dan target kita adalah market atau pasar Internasional untuk UMKM Kota Bandung selain itu juga dalam hal kerjasama ini upaya dalam rangka mendukung program Little Bandung yang memang sudah dipersiapkan selama 
hampir dua tahun terkahir ini semenjak awal 2016 sehingga kita menggandeng program tersebut dalam sebuah kerjasama Sister City yang terjalin antara Kota Bandung dengan Petaling Jaya dibidang ekonomi perdagangan yaitu UMKM itu sendiri, dan ada evaluasi dari hasil kerja per satu tahunnya dalam upaya mencapai target untuk meningkatkan perekonomian Kota Bandung, karena 60\% ekonomi Kota Bandung ini UMKM."

Hasil wawancara tersebut memberikan informasi bahwa Pemerintah Kota Bandung mempunyai progam Little Bandung yang telah dipersiapkan untuk memenuhi target pasar internasional bagi produk-produk UMKM Kota Bandung salah satunya dalam hal kerjasama Sister City dengan Petaling Jaya di bidang ekonomi perdagangan, yang dimana Little Bandung itu sendiri dihadirkan yang sifatnya penggandengan dengan adanya sebuah kerjasama Sister City yang terjalin antara Kota Bandung dengan Petaling Jaya, selain itu Pemerintah Kota Bandung mengadakan evaluasi hasil kerja dalam kurun waktu sekurang kurang nya satu tahun untuk mempromosikan produk UMKM Kota Bandung di Petaling Jaya, serta dalam upaya mendukung untuk meningkatkan perekonomian Kota Bandung.

Selanjutnya hasil wawancara dengan Kasubag Adminstrasi, Dokumentasi, dan Evaluasi Kerjasama SETDA Kota Bandung yang dilakukan pada tanggal 31 Juli 2017 terkait dengan bagaimana kebutuhan Pemerintah Kota Bandung dalam hal kerjasama Sister City dengan Petaling Jaya dibidang ekonomi perdagangan khususnya sektor UMKM serta apa saja target yang ingin dicapai atau diraih oleh Pemerintah Kota Bandung menyatakan bahwa:

"Kota Bandung ini salah satu kota role mode di Indonesia, saatnya memang kita mengusai perdagangan pasar pasar international dengan produk UMKM Kota Bandung, kita persiapkan Little Bandung untuk membuat bandung bandung kecil di negara negara yang ada di dunia."

Hasil wawancara tersebut memberikan informasi kepada peneliti tidak jauh berbeda dengan informan sebelumnya bahwa memang Kota Bandung telah mempersiapkan program Little Bandung untuk saling mendukung antara program Little Bandung itu sendiri dengan kerjasama 
yang dilakukan oleh Pemerintah Kota Bandung yaitu kerjasama Sister City dengan Petaling Jaya di bidang ekonomi perdagangan, yang dimana Little Bandung itu sendiri konsep bukti kesiapan kota Bandung dalam kerjasama yang dilakukan dengan Petaling Jaya dibidang ekonomi perdagangan.

\section{Menilai lingkungan eksternal}

\section{1) Peluang}

Menurut hasil wawancara dengan Kepala seksi Usaha Menengah, Bidang UKM Dinas KUMKM pada tanggal 25 Juli 2017 terkait dengan bagaimana peluang Pemerintah Kota Bandung dalam hal kerjasama Sister City dengan Petaling jaya dibidang ekonomi perdagangan khususnya sektor UMKM menyatakan bahwa:

"Kalau kita berbicara peluang karena memang Indonesia dengan Malaysia serumpun dan lidah orang Malaysia serta gaya berpakaian pun tidak jauh berbeda dengan Indonesia bisa dikatakan peluang Kota Bandung bagus di sana, mereka pun sangat berminat terutama makanan dan pakaian, karena waktu itu kita bawa produk UMKM yang berupa pakaian dan makanan dalam acara pameran Little Bandung laku dan hampir tidak ada yang dibawa lagi."

Hasil wawancara tersebut memberikan informasi kepada peneliti bahwa memang peluang Pemerintah Kota Bandung sangat bagus sekali dalam kerjasama Sister City dengan Petaling Jaya di bidang ekonomi perdagangan khususnya sektor UMKM apabila bisa dimanfaatkan dengan adanya sebuah kerjasama Sister City yang dilakukan oleh Kota Bandung dengan Petaling Jaya dibidang ekonomi perdagangan tersebut, karena memang selera masyarakat Malaysia tidak jauh berbeda dengan Indonesia dapat dikatakan sama. Kemudian hasil wawancara dengan Staff bidang perdagangan regional dan luar negeri seksi exspor impor Dinas Perdagangan dan Perindustrian Kota Bandung pada tanggal 1 Agustus 2017 terkait dengan bagaiamana peluang pemerintah Kota Bandung dalam hal kerjasama Sister City dengan Petaling Jaya di bidang ekonomi perdagangan khsussnya sektor UMKM menyatakan bahwa:

"Kalau peluang hasil Sister City sudah bagus karena kita sudah ada kerjasama dengan pihak Petaling Jaya, karena Petaling Jaya sudah merekomendasikan dan memberikan peluang untuk produk kita promosi disana dan memberikan 
tempat kepada kita Kota Bandung di Paradigm Mall Petaling Jaya dengan membuat Little Bandung Store, peluangnya juga sangat bagus untuk produk karena produk kita semua sudah bisa masuk kesana, selera pun tidak jauh berbeda, bahkan kultur secara budaya secara bahasa itu hampir sama, komunikasi pun bisa berjalan dengan baik, bisa dikatakan peluangnnya sangat bagus karena Pemerintah Kota Bandung pun membuat Market Analysis untuk produk UMKM Kota Bandung di Paradigm Mall Petaling Jaya."

Hasil wawancara tersebut dan dari data yang ada memberikan informasi kepada peneliti bahwa peluang bagi produk-produk UMKM Kota Bandung sangat besar untuk bersaing dengan produk-produk yang ada di Petaling Jaya, karena memang Kota Bandung sudah mempersiapkan konsep Little Bandung dengan adanya sebuah kerjasama Sister City yang dilakukan oleh Kota Bandung dengan Petaling Jaya di bidang ekonomi perdagangan. Kesempatan dan peluang pun sangat besar mengingat secara kultur budaya dan kultur bahasa tidak jauh berbeda karena Indonesia dan Malaysia satu rumpun, hal tersebut pun memudahkan bagi produk produk UMKM Kota Bandung untuk masuk dan bersaing dengan produk-produk yang ada di Petaling Jaya, selain itu juga Little Bandung yang ada di Paradigm Mall Petaling Jaya, bahwa Petaling jaya sendiri adalah salah satu pusat keramaian yang sering dikunjungi terlebih mayarakat Petaling Jaya pun memilik rata-rata pendapatan yang cukup tinggi setiap bulannya.

Selanjutnya hasil wawancara melalui telekomunikasi dengan pihak Petaling Jaya, International Relation Officer Planning Development Department Petaling Jaya City Council pada tanggal 27 Juli 2017 terkait bagaiamana peluang Pemerintah Kota Bandung dalam hal kerjasama Sister City dengan Petaling jaya di bidang ekonomi perdagangan menyatakan bahwa:

"Bagi tujuan ekonomi perdagangan Petaling Jaya telah merekomendasikan dan memfasilitas Kota Bandung selaku teman Sister City dengan memberikan peluang dan ruang di Mall di Petaling Jaya Paradigm Mall secara percuma tanpa dikenakan sebarang pajak atau rental, Petaling Jaya telah mempermudah produk Kota Bandung serta mengkolaborasikan produk-produk Kota Bandung dalam acara acara di Petaling Jaya guna mengundang daya tarik pengunjung" Hasil wawancara tersebut memberikan informasi kepada peneliti 
bahwa Pemerinth Petaling Jaya memberikan akses yang mudah bagi Pemerintah Kota Bandung untuk produk-produkUMKM Kota Bandung di Petaling Jaya dengan merekomendasikan serta memfasilitasi bagi Little Bandung karena adanya sebuah kerjasama Sister City yang dilakukan oleh Pemerintah Kota Bandung dengan Petaling Jaya di bidang ekonomi perdagangan, dalam strategi kerjasama yang dilakukan melalui kolaborasi acara-acara yang dilakukan di Petaling Jaya disi dengan Little Bandung dan produk-produk Petaling Jaya untuk memacu daya tarik."

Dari hasil penelitian terkait bagaiamana peluang Kota Bandung dalam hal kerjasama Sister City dengan Petaling Jaya dibidang ekonomi perdagangan khususnya sektor UMKM bahwa dapat disimpulkan Pemerintah Kota Bandung melakukan sebuah Market Analysis di Petaling Jaya untuk melihat peluang bagi produk-produk Kota Bandung dan melakukan strategi kerjasama dengan Petaling Jaya lewat kolaborasi acara melalui Little Bandung yang ada dan dipersiapkan di Paradigm Mall karena adanya sebuah Kerjasama yang dilakukan oleh Kota Bandung dengan Petaling Jaya.

\section{2) Ancaman}

Ancaman untuk Pemerintah Kota Bandung dalam hal kerjasama Sister City yang dilakukan dengan Petaling Jaya dibidang ekonomi perdagangan, dapat meminimalisir dengan mengetahui ancaman yang datang dari adanya sebuah kerjasama Sister City dengan Petaling Jaya dibidang ekonomi perdagangan khususnya sektor UMKM, sehingga ancaman yang ada bisa dicarikan solusinya untuk menghindari sebuah ancaman. Menurut hasil wawancara dengan dengan Kepala seksi Usaha Menengah, Bidang UKM Dinas KUMKM pada tanggal 25 Juli 2017 terkait bagaimana ancaman untuk Pemerintah Kota Bandung dalam hal kerjasama Sister City dengan Petaling Jaya di bidang ekonomi perdagangan khususnya sektor UMKM menyatakan bahwa:

"Kalau ancaman itu sendiri yang berkembang yang ditakutkan oleh Pemerintah Kota Bandung produk-produk Kota Bandung ditiru oleh Malaysia dan merk-merk produk kita di ambil oleh Malaysia dan dipatenkan oleh Malaysia, akan tetapi Pemerintah Kota Bandung mengantisipasi hal tersebut dengan memfasilitasi produk-produk UMKM Kota Bandung dengan mempatenkan produknya di Bandung itu salah satu cara melindungi produk 
UMKM Kota Bandung, sejauh ini caranya normal-normal saja kita pun tidak ada strategi khusus semacam perjanjian untuk mengatasi sebuah ancaman."

Hasil wawancara tersebut memberikan informasi kepada peneliti bahwa Pemerintah Kota Bandung dalam upaya mengantisipasi terjadinya sebuah ancaman yang datangnya dari pihak luar dalam kerjasama Sister City dengan Petaling Jaya di bidang ekonomi perdagangan sektor UMKM, yaitu dengan cara memberikan hak paten terhadap produk-produk Kota Bandung, antisipasi dari adanya sebuah ancaman produk ditiru dan dipatenkan oleh pihak luar. Kemudian hasil wawancara dengan Staff bidang perdagangan regional dan luar negeri seksi exspor impor Dinas Perdagangan dan Perindustrian Kota Bandung pada tanggal 1 Agustus 2017 terkait bagaiamana ancaman untuk Pemerintah Kota Bandung dalam hal kerjasama Sister City dengan Petaling Jaya di bidang ekonomi perdagangan khususnya sektor UMKM yang dikerjasamakan menyatakan bahwa:

"Ancaman itu memang selalu ada, tapi tidak perlu khawatir kalau memang produk kita punya kreatifitas, sejauh ini memang produk-produk UMKM Kota Bandung punya kreatifitas dan selalu berinovasi. Artinya bahwa produktifitas kita bagus, ancaman yang sejauh ini berkembang pihak 101 Malaysia banyak menjiplak dan membuat produk kita hampir sama, akan tetapi produktifitas kekereatifan ada pada kita Kota Bandung."

Ancaman dalam sebuah kerjasama Sister City dengan Petaling Jaya dibidang ekonomi perdagangan khususnya sektor UMKM yang dilakukan memang ancaman itu selalu ada sejauh ini Pemerintah kota Bandung tidak mempunyai strategi khusus untuk mengatasi ancaman yang berupa SOP suatu intruksi yang terperinci maupun tertulis untuk mengatasinya sehingga kemungkinan-kemungkinan ancaman yang datang itu bisa mengancam setiap saat, akan tetapi Kota Bandung bisa sedikit mengantisipasi atau meminimalisir kemungkinan datangnya sebuah ancaman kepada produk-produk Kota Bandung yang ada di Petaling Jaya 
melalui Little Bandung, dengan cara terus meningkatkan kreatifitas dari produk Kota Bandung itu sendiri, dan Pemerintah Kota Bandung sedikit mempermudah hak paten bagi produk-produk Kota Bandung.

\section{Menilai lingkungan internal}

\section{1) Kekuatan}

Kekuatan yang ada di internal organisasi yang ada di Pemerintah Kota Bandung untuk menjadi sebuah modal dalam menjalankan fungsi dari organisasi dan untuk mencapainya sebuah tujuan organisasi, salah satunya dalam sebuah kerjasama yang dilakukan Pemerintah Kota Bandung dengan Petaling Jaya, kerjasama Sister City dibidang ekonomi perdagangan sektor UMKM khususnya. Menurut hasil wawancara dengan Kasubag Adminstrasi, Dokumentasi, dan Evaluasi Kerjasama SETDA Kota Bandung yang dilakukan pada tanggal 31 Juli 2017 terkait bagaiamana yang menjadi keunggulan kekuatan internal organisasi maupun struktur yang ada didalamnya saat ini yang dapat dipertahankan maupun ditingkatkan sebagai semangat dalam meraih pencapaian target atau tujuan dalam hal kerjasama Sister City menyatakan bahwa:

"Modal yang menjadi kekuatan organisasi didalam internal yaitu aparatur yang luwes atau sigap tanggap merespon segala bentuk pekerjaan yang memang harus dipertahankan, kemampuan untuk menjalin hubungan sesama aparatur dan menjalin sebuah komunikasi dengan baik itu memang harus dimiliki oleh Pemerintah Kota Bandung yang akan menjadi kekuatan untuk menjalin sebuah kerjasama Sister City, karena Pemerintah Kota Bandung menjalin kerjasama dengan Petaling Jaya yang berbeda negara harus menghilangkan rasa kaku."

Hasil wawancara tersebut memberikan informasi kepada peneliti bahwa kekuatan atau keunggulan internal organisasi Pemerintah Kota Bandung yang perlu dipertahankan saat ini adalah dengan terus menerus menajalin sebuah kerjasama Sister City dengan Petaling Jaya, 
serta respon yang baik dari aparatur Pemerintah Kota Bandung menjadi salah satu kekuatan atau keunggulan untuk menjalin sebuah kerjasama Sister City dengan Petaling Jaya,cepat tanggap dari Pemerintah Kota Bandung pun menjadi sebuah kelebihan yang menjadi sebuah kekuatan.

\section{2) Kelemahan}

Untuk mencapai sebuah target atau pun tujuan dari organisasi, organisasi tersebut harus bisa mengurangi atau memperbaiki kelemahan yang ada, agar pencapaian pun terasa maksimal, begitupun dalam kerjasama Sister City Kota Bandung dengan Petaling Jaya di bidang ekonomi perdagangan, yang memang Kota Bandung harus mampu memperbaiki kelemahnnya. Menurut hasil wawancara dengan Kasubag Adminstrasi, Dokumentasi, dan Evaluasi Kerjasama SETDA Kota Bandung yang dilakukan pada tanggal 31 Juli 2017 terkait bagaiamana yang menjadi kelemahan organisasi sehingga menjadi dapat menyebabkan penghalang organisasi dalam mencapai sebuah target maupun tujuan dari kerjasama tersebut menyatakan bahwa:

"Kelemahan yang ada sejauh ini adalah sistem dari pada Pemerintahan Kota Bandung itu sendiri, terutama e-Budgeting yang dimana anggaran bagus memang terperinci setiap bulannya, akan tetapi dengan sebuah rencana dengan anggaran yang telah ditetapkan ketika sebuah rencana meleset tidak sesuai waktu maka anggaran tersebut tidak bisa dipakai disemester berikutnya, apalagi dalam sebuah kerjasama kita perlu juga menyesuaikan dengan pihak yang bekerjasama dalam Sister City ini.”

Dari hasil wawancara tersebut memberikan informasi kepada peneliti bahwa seharusnya dinas-dinas yang ada di Pemerintahan Kota Bandung merencanakan program kerja terkait dengan Kerjasama Sister City yang dilakukan haruslah benar-benar matang, karena sudah masuk dalam e-budgeting yang telah dianggarkan. Ketidaksiapan Pemerintah akan menjadi penghambat dalam sebuah tujuan. 


\section{E. Mengidentifikasi isu strategis yang dihadapi organisasi}

\section{1) Kualitas Sumber Daya Manusia}

Kualitas sumber daya manusia dalam upaya mendukung kerjasama Sister City Kota Bandung dengan Petaling Jaya dibidang ekonomi perdagangan khsusunya sektor UMKM, kualitas sumber daya manusia menjadi faktor yang sangat penting untuk menunjang sebuah tujuan organisasi dalam hal sebuah kerjasama Sister City Kota Bandung dengan Petaling Jaya di bidang ekonomi perdagangan, apabila kualitas sumber daya manusia tidak memadai maka kejrasama Sister City Kota Bandung dengan Petaling Jaya dibidang ekonomi perdagangan khususnya sektor UMKM tidak dapat dilaksanakan secara optimal.

Menurut hasil wawancara dengan dengan Kepala seksi Usaha Menengah, Bidang UKM Dinas KUMKM pada tanggal 25 Juli 2017 terkait bagaiamana kualitas sumber daya manusia yang ada di Kota Bandung saat ini khususnya dalam hal kerjasama Sister City dibidang ekonomi perdagangan khususnya sektor UMKM menyatakan bahwa:

"Kalau melihat sumber daya manusia, terutama di UMKM Pemerintah Kota Bandung sering mengadakan semacam pelatihan atau bimtek atau juga sekarang semamacam wirausaha baru itu dalam rangka mendukung UMKM Kota Bandung dan Pemerintah Kota Bandung pun memberikan arahan atau panduan semacam modul agar para pelaku UMKM ini tau bagaimana cara pembukuan, harga bahan pokok dan target harga jual, sejauh ini bisa dikatakan kualitas UMKM sangat mendukung."

Dari hasil wawancara tersebut memberikan informasi kepada peneliti bahwa Pemerintah Kota Bandung berupaya dalam hal meningkatkan kualitas sumber daya manusia khususnya di sektor UMKM dengan cara mengadakan sebuah pelatihan yang memang diharapkan bisa terus meningkatkan keterampilan dan kualitas sumber daya manusia yang ada di Kota Bandung dalam hal sektor UMKM itu sendiri, sehingga bisa bersaing dan mengahsilkan produk yang berkualitas nantinya.

Menurut hasil wawancara dengan dengan dengan Staff bidang perdagangan regional dan luar negeri seksi exspor impor Dinas 
Perdagangan dan Perindustrian Kota Bandung pada tanggal 1 Agustus 2017 terkait bagaiamana kualitas sumber daya manusia yang ada di Kota Bandung saat ini khususnya dalam 107 hal kerjasama Sister City dibidang ekonomi perdagangan khususnya sektor UMKM menyatakan bahwa:

"Karena memang kita kerjasama tidak hanya dengan Petaling Jaya saja dengan beberapa negera lain juga kita kerjasama Sister City, kualitas sumber daya manusia di Kota Bandung khsusunya sektor UMKM sudah baik tapi kita perlu tingkatkatkan lagi mengenai pengusaan bahasa salah satunya bahasa inggris harus menguasai agar interaksi dari kerjasama tersebut bisa berjalan dengan baik, makanya Pemerintah Kota Bandung menerapkan kamis inggris salah satu tujuannya untuk menunjang hal tersebut meningkatkan kualitas sumber daya manusia di Kota Bandung."

Selain melakukan wawancara, peneliti juga melakukan observasi terhadap kualitas sumber daya manusia di Kota Bandung khususnya yang berkaitan dengan kerjasama Sister City yang dilakukan Pemeerintah Kota Bandung menunjukan bahwa sebenarnya beberapa aparatur di Pemerintah Kota Bandung ada yang telah menguasai bahasa dengan baik akan tetapi tidak semua, misalnya di hari Kamis Inggris ada beberapa aparatur yang interaksi sesekali memakai Bahasa Inggris sisanya cenderung memilih diam tidak berbicara.

\section{2) Kualitas Usaha Mikro Kecil Menengah}

UMKM Kota Bandung harus mempunyai kualitas yang baik, karena kualitas UMKM yang baik dapat bersaing dengan produkproduk luar. Hal tersebut dianggap sangat penting, kualitas UMKM yang baik akan mendorong daya tarik pembeli terhadap produk UMKM itu sendiri, apalagi berkaitan dengan kerjasama Sister City Kota Bandung dengan Petaling Jaya di bidang ekonomi perdagangan diharapkan dapat mengoptimalkan kerjasama tersebut salah satunya dengan meningkatkan kualitas UMKM itu sendiri.

Menurut hasil wawancara dengan dengan Kepala seksi Usaha Menengah, Bidang UKM Dinas KUMKM pada tanggal 25 Juli 2017 terkait bagaiamana kualitas UMKM Kota Bandung saat ini apakah mampu bersaing dengan produk- produk luar menyatakan bahwa: 
"Kalau kita lihat, dengan program Little Bandung yang sudah dijalankan dibeberapa negara salah satunya di Petaling Jaya karena adanya sebuah kerjasama Sister City artinya bahwa kualitas UMKM Kota Bandung sudah bagus dan sudah siap bersaing dengan produk-produk luar apalagi jenis produk UMKM Kita terutatama jenis Fashion seperti baju celana jaket dan sepatu banayal peminatnya di luar negeri salah satunya di Petaling Jaya Malaysia yang sudah terjalin kerjasama Sister City, karena UMKM Kota Bandung yang di jual adalah kreatifitas UMKM nya itu sendiri, semua orang bisa meniru produk kita tapi tidak akan bisa mengambil atau meniru kreatifitas kita karena itu yang bermain skill."

Hasil wawancara tersebut memberikan informasi kepada peneliti bahwasannya dengan adanya sebuah program Little Bandung dan salah satunya sudah dilaksanakan atau dijalankan di Petaling Jaya, itu menandakan bahwa kualitas UMKM Kota Bandung sudah baik karena siap bersaing dengan produk-produk yang ada di Petaling Jaya atau produk luar, kreatifitas tinggi yang dimiliki UMKM Kota Bandung menjadi modal utama sat ini untuk terus mendorong daya saing atau daya jual produk UMKM Kota Bandung, dari beberapa jenis UMKM yang ada di Little Bandung seperti Fashion, Craft, Kuliner dan Kerajinan yang paling banyak dimintai jenis Fashion dan Craft sedangkan yang lainnya masih dibawah, hal ini karena sebenernya bisa terus ditingkatkan dari semua jenis produk UMKM Kota Bandung yang ada di Little Bandung dalam sebuah kerjasama Sister City dengan Petaling Jaya Malaysia apabila promosi terus menerus dilakukan oleh Pemerintah Kota Bandung khususnya oleh Dinas Perdagangan dan Perindustrian dan Dinas Koperasi Usaha Mikro Kecil Menengah dilakukan secara terus menerus.

Hasil wawancara dengan pemilik atau owner produk UMKM Awie Bah Akim salah satu produk yang terdaftar di Little Bandung pada tanggal 12 Juli 2017 terkait bagaiamana kualitas UMKM Kota Bandung apakah mampu bersaing dengan produk-produk dari luar menyatakan bahwa:

"Kualitas UMKM sebenarnya sudah bagus dan bisa bersaing hanya saja terkadang terkendala dalam permodalaan dan bahan baku yang terkadang susah juga, sehingga menghambat 
perkembangannya UMKM nya itu sendiri akan tetapi secara keseluruhan saat ini kualitas UMKM Kota Bandung bisa dikatakan siap untuk bersaing dengan produk-produk luar, kualitasnya hampir sudah banyak yang bagus jadi tidak ada yang perlu dikhawatirkan lagi jika bersaing dengan produkproduk luar mengingat UMKM Kota Bandung punya kualitas di level yang baik."

Hasil wawancara tersebut memberikan informasi kepada peneliti bahwa kualitas UMKM bisa terus meningkatkan kualitasnya apabila modal tidak menjadi persoalaan lagi, pada intinya para pelaku UMKM bisa mengexlplorasi kreatifitasnya apabila didukung dengan modal yang baik dalam pembuatan atau pengembangan produk UMKM itu sendiri, pelaku UMKM merasa sangat siap saat ini bersaing dengan produk luar. Selain melakukan wawancara peneliti juga melakukan observasi terhadap para pelaku UMKM berkaitan dengan kualiitas UMKM peneliti melihat bahwa pelaku UMKM sangat teliti dalam pengerjaan pembuatan produk untuk menjaga kualitas, bahwa UMKM Kota Bandung mengutamakan kepuasaan tinggi bagi konsumennya.

\section{KESIMPULAN}

Berdasarkan hasil penelitian dan pembahasan mengenai Strategi Kerjasama Sister City Kota Bandung dengan Petaling Jaya di bidang ekonomi perdagangan ini, strategi yang dilakukan Pemerintah Kota Bandung sudah berjalan dengan baik akan tetapi masih belum optimal. Strategi kerjasama Sister City Kota Bandung dengan Petaling Jaya di bidang ekonomi perdagangan dilihat dari dimensi strategi yaitu:

1. Dari proses Mencapai Menyepakati antara Pemerintah Kota Bandung dengan Petaling Jaya bahwa Pemerintah Kota Bandung telah mencapai dan menyepakati suatu proses dalam sebuah kerjasama Sister City dengan Petaling Jaya di bidang ekonomi perdagangan diantarannya menghasilkan akses pasar internasional untuk produk-produk UMKM Kota Bandung melalui program Little Bandung, sarana dan prasana dalam kerjasama Sister City dengan Petaling Jaya dibidang ekonomi perdagangan pun sudah 
memadai, karena memang Petaling Jaya pun memfasilitasi dan merekomendasikan tempat untuk Kota Bandung di Petaling Jaya serta melakukan sebuah strategi kerjasama melalui koloborasi dalam kegiatankegiatan promosi di Petaling Jaya.

2. Mengidentifikasi Mandat Organisasi, bahwa identifikasi suatu kebutuhan dalam hal kerjasama Sister City Kota Bandung dengan Petaling Jaya di bidang ekonomi perdagangan, seperti fisik, financial dan sumber daya manusia sejauh ini masih bisa terpenuhi dengan baik dalam mencapai sebuah target yang ingin dicapai dari Pemerintah Kota Bandung dengan Petaling Jaya di bidang ekonomi perdagangan.

3. Menilai Lingkungan Eksternal, bahwa peluang untuk Kota Bandung dalam hal kerjasama Sister City dengan Petaling Jaya di bidang ekonomi perdagangan sangat besar karena memang produk-produk UMKM Kota Bandung semua bisa diterima melalui program Little Bandung, adapun ancaman yang datang masih bsa teratasi.

4. Menilai Lingkungan Internal, bahwa Pemerintah Kota Bandung mempunyai semangat yang baik dalam hal kerjasama Sister City dengan Petaling jaya di bidang ekonomi perdagangan khususnya sektor UMKM hal tersebut pun bisa terus dipertahankan, dan kelemahan yang selama ini terjadi berada pada sebuah perencanaannya itu sendiri.

5. Mengidentifikasi isu strategis yang dihadapi organisasi, bahwa kualitas sumber daya manusia di Kota Bandung cukup siap, dan kualitas UMKM pun sudah pada level yang baik. Akan tetapi dua-duanya perlu ditingkatkan lagi dari beberpa kekurangan yang ada.

\section{DAFTAR PUSTAKA}

Keban, Jeremias,T. 2007. Membangun Kerjasama Antar Pemerintah Daerah Dalam Era Otonomi. Jurnal Ilmu Pemerintahan Indonesia. Jakarta.

Pamudji.S. 1985. Kerjasama antar pemerintah daerah Dalam Rangka Pembinaan Wilaya Suatu Tinjuan Dari Segi Administrasi Negara. Bina Aksara. Jakarta. 
Pratikno. 2007. Kerjasam antar Daerah: Kompleksitas dan Tawaran Format Kelembagaan. UGM. Yogyakarta

Rosen dalam Keban. (2007). Enam Dimensi Strategi Administrasi Publik: Konsep, Teori, dan Isu. Yogyakarta: Gava Media.

Sugiyono. 2012. Memahami Penelitian Kualitatif. Bandung : CV Alfabeta.

\section{Dokumen-dokumen:}

Surat Kuasa Menteri Luar Negeri Indonesia No.078/FP/BK/11/2015.

Letter Of Intent Kota Bandung-Petaling Jaya 2012.

Surat MOU Sister City Kota Bandung-Petaling Jaya 2015.

\section{Sumber-sumber lainnya:}

$\underline{\text { www.bdg.ksln.co.id }}$

www.littlebandung.co.id

https://ppid.bandung.go.id 